\title{
A Systematic Review of in vitro Studies Conducted on Effect of Herbal Products on Secretion of Insulin from Langerhans Islets
}

\author{
Ozra Tabatabaei-Malazy ${ }^{1}$, Bagher Larijani ${ }^{1}$, Mohammad Abdollahi ${ }^{1,2}$ \\ ${ }^{1}$ Endocrinology and Metabolism Research Center, Tehran University of Medical Sciences, Tehran, Iran \\ ${ }^{2}$ Faculty of Pharmacy, and Pharmaceutical Sciences Research Center, Tehran University of Medical Sciences, Tehran, Iran
}

Received, June 4, 2012; Revised, July 23, 2012; Accepted, July 24, 2012; Published July 27, 2012

\begin{abstract}
Purpose: Diabetes mellitus is the most important health problem that its prevalence is increasing. Diabetes is characterized by defects in insulin secretion, insulin action or both. Recent studies provided evidences that loss of functional $\beta$-cell mass through apoptosis is central to the development of diabetes. The management of diabetes without any side effects is still a challenge to the medical system. Recently, there has been a special interest to herbal medicine in care and management of diabetes due to their natural origin and less side effects. The current systematic review focuses on main component of antidiabetic plants with directly effect on insulin secretion of pancreas. Methods: All in vitro studies which assessed the potential effect of, main components, multi herbal, whole plant, or extract of the plants directly on pancreatic insulin secretion published from 2001 to November 2011 were included. Exclusion criteria were clinical trial studies that did not assess insulin secretion, and review articles, or letters to the editor. Results: The majority of these studies showed that the improvement of $\beta$-cell function and insulin secretion is possible with antioxidant compounds. Suppression of oxidative stress, cytokine-induced impairment, suppression of nuclear factor $\kappa \mathrm{B}$ a key regulator of endothelial activation, activation of uncoupling protein 2 (UCP2), insulin-like activity and increasing intracellular calcium, were among the most important indicated pathways. Conclusions: By considering the role of oxidative stress in pathogenesis of $\beta$-cell dysfunction, antioxidant compounds could be helpful in management of diabetes and its complications.
\end{abstract}

This article is open to POST-PUBLICATION REVIEW. Registered readers (see "For Readers") may comment by clicking on ABSTRACT on the issue's contents page.

\section{INTRODUCTION}

It is estimated that diabetes mellitus (DM) affects more than 366 million people worldwide and it is expected that the figure reach a staggering 552 million by 2030 (1). DM is a multifactorial disease characterized by chronic hyperglycemia due to defects in insulin secretion, insulin action or both, resulting from a deficit in $\beta$-cell mass $(2,3)$. Several mechanisms have been proposed for $\beta$-cell destruction, including damage from inflammatory cytokines, circulatory free fatty acids, and hyperglycemia $(4,5)$. The management of DM without any side effects is still a challenge to the medical system. Although, the synthetic products are widely used in clinical settings for more than 50 years, they are associated with various undesirable side effects such as hypoglycemia. In the last few years, there has been a growing interest to herbal medicine in care and management of diabetes both in developing and developed countries, due to their natural origin and less side effects (6-9).

Wide array of plants are demonstrated to have antidiabetic activity. Biological actions of these plants are related to chemical composition of the plant products. Herbal products that are rich in phenolic compounds, alkaloids, flavonoids, terpenoids, coumarins, and glycosides usually show positive effects (6). On the other hand, many conventional drugs for treatment of diabetes such as metformin are secretagogues and have plants origin (10). The World Health Organization expert committee on diabetes has listed as one of its recommendations that traditional medical plants as methods of treatment of diabetes should be further investigated (11).

Corresponding Author: Mohammad Abdollahi, Professor, Faculty of Pharmacy, and Pharmaceutical Sciences Research Center, Tehran University of Medical Sciences, Tehran, Iran. Email: Mohammad.Abdollahi@UToronto.ca 
Insulin is the most important peptide hormone that is secreted from the islet $\beta$-cells of langerhans in response to hyperglycemia but in a complex process. The first step in this process is an increase in production of adenosine triphosphate (ATP) from adenosine diphosphate which leads to an increased ATP/ADP ratio in the cytoplasm with subsequent closing of ATP-sensitive potassium channels (12). Depolarization of plasma membrane could activate the voltage-dependent $\mathrm{Ca}^{2+}$ channels and hence $\mathrm{Ca}^{2+}$ influx. The increase in intracellular concentration of $\mathrm{Ca}^{2+}$ triggers the insulin secretion (13). These pathways can be exhibited in diabetes and results in abnormal pattern of insulin secretion (13). Some studies provided evidences that loss of functional $\beta$ cell mass through apoptosis is central to the development of both type 1 (14) and type 2 diabetes (15). Proliferation of islet $\beta$-cells is a very important component of $\beta$-cell adaptation to increased apoptosis and insulin resistance. Similarly by the strategy to induce $\beta$-cell proliferation and preserving functional $\beta$-cell mass, it would be possible to prevent the onset of diabetes $(14,16-$ 20). Approaches to achieve this objective are stimulation of insulin secretion and inhibition of $\beta$ cell apoptosis (21).

Many medicinal plants modulate the expression, synthesis and degradation of insulin. Induction of insulin release is the main mechanism of action for some antidiabetic plants (22); however increase in islet number and size as well as producing the antioxidative effects could be accounted as anti-diabetic mechanism of action of some other herbal medicine (7). Besides, antidiabetic effects of these compounds, the other benefit of such insulin releasers are looked in islet transplantation which is the final step in management of diabetic type 1 and sometimes progressive type 2 patients. The bottle neck in the islets transplantation is to keep them survived and functional during isolation before transplantation. The belief is that direct treatment of insulin producing cells or pancreatic islets with different herbal products improves their viability and function. Therefore, this could be a novel approach for improving the outcome of islet transplantation. The current systematic review is a novel work that focused on main components of plants with antidiabetic effects acting directly on insulin secretion of pancreatic islet cells.

\section{METHODS}

To obtain all related studies, Google Scholar, PubMed, Web of Science, and Scopus databases from 2001 to November 2011 were searched. The search terms used were as follows: "insulin secretion", "insulin-secreting cell", "insulin release", " islet" and "herbal or natural product" and their synonym in Persian databases of IranMedex, and Magiran. We found many in vitro studies which focused on antidiabetic plants, but they did not assess the effect on insulin secretion. Therefore all available in vitro studies which assessed the potential effect of, main components, multi herbal, whole plant, or extract of the plants directly on insulin secretion of isolated islet cells (or insulinsecreting cell lines such as RIN, HIT, $\beta$-TC, MIN6, INS-1) of pancreas were included. Exclusion criteria were clinical trials that did not assess insulin secretion, and review articles, or letters to the editor. Thesis and other unpublished data were not included. The title and abstract of all of search results were examined to eliminate the duplication. Also, the reference lists of articles were reviewed for additional relevant studies.

\section{RESULTS}

The number of initial search results and included studies are shown in the Figure 1. Forty-nine articles were selected as our final research database (23-71). The summary of these studies are shown in Table 1. These studies showed that herbal products can increase insulin secretion by affecting different steps of this process. Suppression of oxidative stress, cytokine-induced impairment, suppression of nuclear factor $\kappa \mathrm{B}(\mathrm{NF}-\kappa \mathrm{B})$; NF- $\kappa \mathrm{B}$ is a key regulator of endothelial activation; uncoupling protein 2 (UCP2) activation, and increasing intracellular $\mathrm{Ca}^{2+}$, are among the most important indicated pathways (23-72).

\section{DISCUSSION}

\section{In vitro studies on insulin secretion}

The majority of experimental studies published between 2001 and 2011 were carried out on rats or mice. In addition, the most frequently drugs used for induction of diabetes were streptozotocin (STZ) and alloxan. 


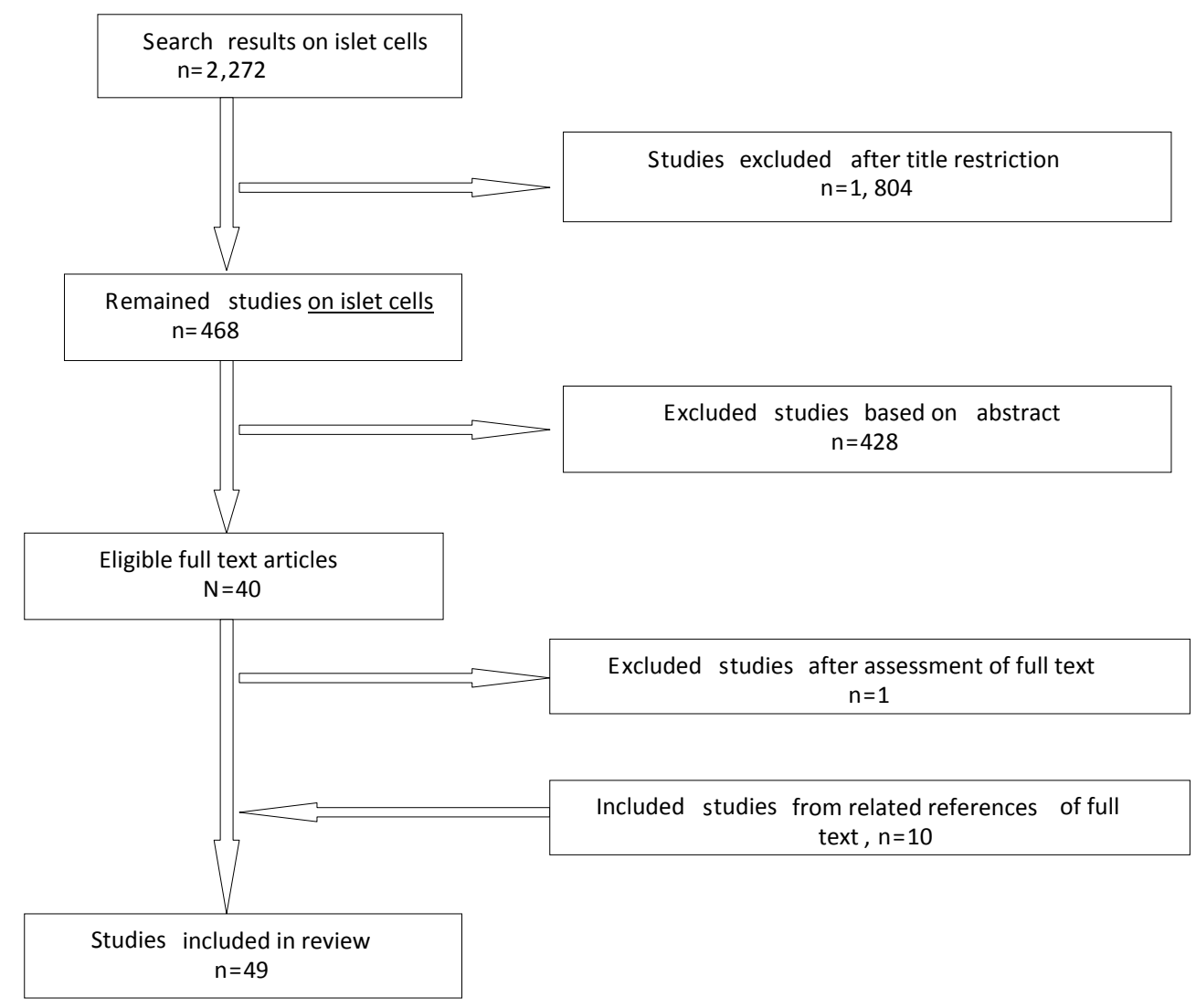

Figure 1. Flow diagram of the study selection process

It was established that these models are useful for study of multiple aspects of diabetes $(73,74)$. The cytotoxic action of these diabetogenic agents is mediated by reactive oxygen species (ROS) with some differences in their mechanism of action. By formation of superoxide radicals, alloxan can stimulate massive increase in cytosolic calcium concentration which leads to destruction of $\beta$-cells of pancreas (75). STZ enters the $\beta$-cell via glucose transporter 2 (GLUT2) and causes DNA alkylation. In addition, by activation of poly adenosine diphosphate ribosylation it causes nitric oxide (NO) release and necrosis of pancreatic $\beta$-cells (74).

\section{Effect on insulin secretion by suppression of oxidative stress}

We found that the potential antidiabetic activity of the published in vitro studies can affect different steps of insulin secretion. Because many of plants that were included in our study had more than a single active component, the observed hypoglycemic behaviors may be related to the combined synergistic actions. Some of them showed antidiabetic activity by improving oxidative metabolisms. Broussonitia Kazinoki (23), Saururus Chinensis Baill (24), American Ginseng (42), Commiphora Mukul (43), Germinated Fenugreek (51), Rhizoma Coptidis (57), and Curcuma Longa (58), Pueraria Lobata (62) are the examples of presence of antioxidant activity in the medicinal plants. Flavonoids Rhizoma Coptidis (57), and Curcuma Longa (58), Pueraria Lobata (62) posse hypoglycemic as well as antioxidant properties. Quercetin is an important flavonoid that increases insulin secretion by enhancing hepatic glucokinase activity (76) or changing intracellular calcium concentration (77). Quercetin in combination with apigenin and luteolin as flavonoids increased the viability of $\beta$-cells, insulin secretion, and cytokineinduced cytotoxicity resistance, and decreased NOsynthase (iNOS) and NF- $\kappa B$ activation (55). Flavonoids can also prevent cytokine-induced $\beta$-cell damage by declining NF- $\mathrm{BB}$ signaling (78-80). In addition, the flavonoids have phosphodiesterase 
inhibitor (PDEI) activities (81). Another main plant compounds with PDEI activity are alkaloids, saponins, lignans, and coumarins. Some benefits of PDEI activity especially in diabetic patients include anti-inflammatory and antioxidant effects (81), and improvement of isolated islet cells function (82).

Genistein and soy isoflavonoids could significantly increase the insulin secretion by enhancing kcl-stimulated insulin secretion, increasing intracellular calcium concentration, and inhibiting extracellular signal-related kinase-1/2 (ERK-1/2), Janus kinase/signal transducer and activator of transcription pathway (JAK/STAT) or $\mathrm{NF}-\kappa \mathrm{B}$ activation $(32,56)$. Activated ERK1/2 plays a pivotal role in environmentally-stimulated cellular responses, including cellular proliferation, growth, and differentiation. It is observed that genistein induces a rapid ERK1/2 phosphorylation, which may be necessary for growth factors to drive $\beta$-cell proliferation (83). Puerarin, an isoflavone, could increase insulin secretion by decreasing free radical production and increasing catalase (CAT) and superoxide dismutase (SOD) activities (62). Curcumin is a polyphenolic compound that is an inhibitor of NF- $\kappa \mathrm{B}$. Various biological activities for curcumin such as anti inflammatory and antioxidant make it helpful in increasing area and numbers of islets and secretion of insulin $(40,58)$.

An association has been shown between oxidative stress and occurrence of several diseases, such as cardiovascular, diabetes, and metabolic syndrome (84-86). Oxidative stress is a phenomenon associated with the action of free radicals and reactive metabolites in the organism (87). It has been shown that both types of antioxidants, enzymatic (SOD, CAT, GPx) and nonenzymatic (vitamin $\mathrm{C}$, vitamin $\mathrm{E}$, zinc, uric acid and selenium), act against oxidants (87). Free radicals are derived from basic radical molecules such as superoxide anion radical or NO (88). When NO is produced by catalytic action of iNOS, it can cause a damage to proteins, lipids and DNA either directly or after reaction with superoxide (89). Taking together, it is evident that increased production of free radicals has a central role in development of diabetes complications (9). The NF- $\mathrm{KB}$ is activated by free fatty acids, inflammatory cytokines, and the receptor for advanced glycation end products (RAGE) (90-92). Studies in cultured endothelial cells and experimental animals have shown an association between activation of NF- $\kappa B$, development of an inflammatory phenotype, insulin resistance, and impaired bioactivity of $\mathrm{NO}(93,94)$. By considering the fact that there is a strong association between oxidative stress and diabetes, the use of antioxidants should be helpful for management of diabetes (95-99). In the recent years, the positive antioxidant effects of some antidiabetic herbal products are established. Some of these medicinal herbs include species of Satureja (100), Urtica (101), Teucrium (102). As islet cell transplantation procedure is faced with oxidative stress, some studies with herbal products are investigated to assess their antidiabetic effects on isolated islet cells and showed positive effects. These substances include Setarud (IMOD); a mixture of Rosa canina, Tanacetumvulgare and Urtica dioica comprising selenium and urea treated by pulsed electromagnetic field of high frequency (25), specific PDEIs; milrinon, rolipram, sildenafil (82), calcium channel blockers, autonomic nervous system blockers and free radical scavengers; nanoparticles of cerium (103).

\section{Effect on insulin secretion by insulin like activity}

Adipose tissue enhances lipotoxicity by increasing intracellular lipid levels and also insulin resistance (104). So, adipose tissue as a key link between obesity and diabetes was assessed for the effects of natural products on glucose uptake. On the other hand, the classic target tissues of insulin which include hepatocytes, adipose tissue and skeletal muscle play important roles in homeostasis of glucose upon glucose uptake. Sarcopoterium Spinosum (31), Rooibos (33), Nigella Sativa L (36), Cichorium Intybus (48), Momordica Charantia (63) are the examples of natural products with insulinlike effects. This effect is attributed to some of antidiabetic compounds such as chlorogenic acid and caffeic acid (48). Chlorogenic acid by inhibiting glucose-6-phosphatase (G6P) in microsomes of liver suppresses gluconeogenesis and glycogenolysis and consequently reduces the hyperglycemia. In addition, G6P inhibition leads to increase glucose transport and its utilization. Finally it can stimulate insulin secretion through increased production of ATP (105).

\section{Effect on insulin secretion through increasing viability and proliferation of $\beta$-cells}

It is well established that replacing $\beta$-cells by islet transplantation has the potential to cure type $1 \mathrm{DM}$ 
and on the other hand the efficacy of islet transplantation depends upon number and state of functional islet cells (106). Apoptosis affects the initial stage of islet transplantation which yields non-functional cells. Human pancreas contains an average one million islet cells (107) and in a good isolation process, a total of 500,000 islets with more than $80 \%$ viability can be obtained. Since the viability of islets is affected by numerous factors in the early or late period of post transplantation (108), isolated procedure would be given lower yield (109, 110). Thus, islet yield and its post-transplant survival remain major issues. During initial stage of islet transplantation, islet cells are avascular and suspected to hypoxic ischemia condition which is produced by oxidative stress (96). Astragalus Membranaceus Bge (38), Codonnopsis Pilosula Nannf (38), Lycium Chinense Mill (38), Green Tea (48), Coptidis Rhizoma (65) are natural products with suppression effect on apoptosis. Some medicinal plants such as Nigella Sativa L (36) can increase insulin secretion by including proliferation of islet cells. In our study, we found other antidiabetic plants that show their effects by increasing islet cell viability. Sarcopoterium Spinosum (31), Cornus Officinalis Sieb. et Zucc (39), Germinated Fenugreek (51), Rhizoma Coptidis (57), Curcuma Longa (58) are the examples of plants with this effect. All of these plants have antioxidant effects and the observed antidiabetic effects may be related to combination of these mechanisms.

\section{Effect on insulin secretion through ATP/ADP ratio and intracellular $\mathrm{Ca}^{2+}$ concentration}

There are other mechanisms that have direct effects on insulin secretion $(111,112)$. These mechanisms are ATP/ADP ratio and intracellular $\mathrm{Ca}^{2+}$ concentration which have been described previously $(12,13)$. The examples of the natural products with these effects are as follows: Angelica Hirsutiflora (34), Stevia Rebaudiana Bertoni (37, 66), Korean Red Ginseng (41), Asparagus Racemosus (53), Ocium Sanctum (60), and Gardenia Jasmine Ides Ellis (64).

\section{Effect on insulin secretion through inhibition UCP2}

$\mathrm{UCP} 2$ as a mitochondrial carrier protein is expressed in islets of pancreas and has negative effect on glucose-stimulated insulin secretion (113).
Animal $(114,115)$ and human $(116,117)$ studies have shown that increased UCP2 expression in islets can lead to $\beta$-cell dysfunction and development of type 2 diabetes mellitus. Thus, UCP2 deficiency can prevent $\beta$-cell dysfunction. The KYQRF formula (28) which is a combination of several medicinal plants, and Gardenia Jasmine Ides Ellis (64) markedly suppresses UCP2.

In this review, however, we had some limitations. We focused and included only the studies with in vitro analysis. Unfortunately, in vitro studies do not reflect all the aspect of in vivo application of new treatments, as most in vitro models consider single cell types, metabolic pathway or enzyme involvement. This greatly reduces the possibility of identifying the antidiabetic plant extracts or compounds (118). Another disadvantage of in vitro studies is that only acute or immediate effects are measured, whilst effects that may only appear after chronic exposure to the antidiabetic compounds are overlooked (118). Hence, there is need to carry out in vivo studies on these antidiabetic plants.

The major mode of action of medicinal plants with antidiabetic activity is to increase insulin secretion. Some mechanisms of actions were related to their effects on the activity of pancreatic $\beta$-cells or the insulin-like activity of the plant extracts, or directly stimulation of insulin secretion or suppression of oxidative stress. All of these actions may be responsible for the reduction and or abolition of diabetic complications. As many of the studied plants showed more than one effective mechanism in increasing islet insulin secretion, the observed hypoglycemic behaviors may be due to a combination of synergistic mechanisms. However, the benefits of antioxidants in management of diabetes could not be ignored (119). Future investigations should focus on antioxidant mixtures as an appropriate formula for management of diabetes.

\section{ACKNOWLEDGEMENT}

This paper is the outcome of an in-house study with no external financial support.

\section{REFERENCES}

1. IDF diabetes atlas- fifth edition. 2011 International Diabetes Federation. Available from www.idf.org/diabetesatlas/papers. 
2. WHO. Definition, diagnosis and classification of diabetes mellitus and its complications: report of a WHO consultation, Part 1: diagnosis and classification of diabetes mellitus. World Health Organization 1999, Geneva.

3. Harris M, Zimmet P. Classification of diabetes mellitus and other categories of glucose intolerance, In: Alberti K, Zimmet P, Defronzo $\mathrm{R}(\mathrm{eds})$ : International textbook of diabetes mellitus. 2nd ed., Chichester: John Wiley and Sons, pp 9-23, 1997.

4. Maedler K, Sergeev P, Ris F, Oberholzer J, JollerJemelka HI, Spinas GA, Kaiser N, Halban PA, Donath MY. Glucose-induced $\beta$ cell production of IL-1 $\beta$ contributes to glucotoxicity in human pancreatic islets. J Clin Invest 2002; 110: 851-860.

5. Shimabukuro M, Koyama K, Lee Y, Unger RH. Leptin- or troglitazone-induced lipopenia protects islets from interleukin $1 \beta$ cytotoxicity. J Clin Invest 1997; 100: 1750-1754.

6. Modak M, Dixit P, Londhe J, Ghaskadbi S, Paul A. Devasagayam T. Indian herbs and herbal drugs for the treatment of diabetes. J Clin Biochem Nutr 2007; 40: 163-173.

7. Hasani- Ranjbar S, Larijani B, Abdollahi M. A systematic review of Iranian medicinal plants useful in diabetes mellitus. Arch Med Sci 2008; 4: 285-292.

8. Hasani-Ranjbar S, Larijani B, Abdollahi M. A systematic review of the potential herbal sources of future drugs effective in oxidant-related diseases. Inflamm Allergy Drug Targets 2009; 8: 2-10.

9. Rahimi R, Nikfar S, Larijani B, Abdollahi M. A review on the role of antioxidants in the management of diabetes and its complications. Biomed Pharmacother 2005; 59: 365-373.

10. Grover JK, Yadav S, Vats V. Medicinal plants of India with anti-diabetic potential. J Ethnopharmacol 2002;81: 81-100.

11. WHO Expert committee on diabetes mellitus: second report, World Health Organ. Tech Rep Ser 1980; 646:1-80

12. Affourtit C, Brand MD. Stronger control of ATP/ADP by proton leak in pancreatic beta-cells than skeletal muscle mitochondria. Biochem J 2006; 393: 151-159.

13. Ashcroft FM, Rorsman P. Molecular defects in insulin secretion in type-2 diabetes. Rev Endocr Metab Disord 2004; 5: 135-142.

14. Tourrel C, Bailbe D, Lacorne M, Meile MJ, Kergoat M, Portha B. Persistent improvement of type 2 diabetes in the Goto- Kakizaki rat model by expansion of the $\beta$-cell mass during the prediabetic period with glucagon-like peptide-1 or exendin-4. Diabetes 2002; 51: 1443-1452.
15. Sakuraba H, Mizukami H, Yagihashi N, Wada R, Hanyu C, Yagihashi S. Reduced $\beta$-cell mass and expression of oxidative stress-related DNA damage in the islet of Japanese type II diabetic patients. Diabetologia 2002; 45: 85-96.

16. Suarez-Pinzon WL, Yan Y, Power R, Brand SJ, Rabinovitch A. Combination therapy with epidermal growth factor and gastrin increases $\beta$-cell mass and reverses hyperglycemia in diabetic NOD mice. Diabetes 2005; 54: 2596-2601.

17. Stoffers DA. The development of $\beta$-cell mass: recent progress and potential role of GLP-1. Horm Metab Res 2004; 36: 811-821.

18. Sreenan S, Pick AJ, Levisetti M, Baldwin AC, Pugh W, Polonsky KS. Increased $\beta$-cell proliferation and reduced mass before diabetes onset in the nonobese diabetic mouse. Diabetes 1999; 48: 989-996.

19. Wang Q, Brubaker PL. Glucagon-like peptide-1 treatment delays the onset of diabetes in 8-weekold db/db mice. Diabetologia 2002; 45: 1263-1273.

20. Rolin B, Larsen MO, Gotfredsenet CF, Deacon CF, Carr RD, Wilken M, Knudsen LB. The longacting GLP-1 derivative NN2211 ameliorates glycemia and increases $\beta$-cell mass in diabetic mice. Am J Physiol Endocrinol Metab 2002; 283: E745-752.

21. Ahren B. Type 2 diabetes, insulin secretion and $\beta$ cell mass. Curr Mol Med 2005; 5: 275-286.

22. Frode TS, Medeiros YS. Animal models to test drugs with potential antidiabetic activity. J Ethnopharmacol 2008; 115:173-183.

23. Bae UJ, Lee DY, Song MY, Lee SM, Park JW, Ryu JH, Park BH. A prenylatedflavan from Broussonetiakazinoki prevents cytokine-induced bcell death through suppression of nuclear factor-KB activity. Biol Pharm Bull 2011; 34: 1026-1031.

24. Jeong GS, Lee DS, Park BH, Kwon KB, Kim YC. Sauchinone protects pancreatic $b$ cells against cytokine-mediated toxicity. Toxicol in Vitro 2011; 25: 505-512.

25. Larijani B, Salimi M, Pourkhalili N, Mohammadirad A, Baeeri M, Nili-Ahmadabadi A, Abdollahi M. Positive response of isolated rat pancreatic islets to IMOD; hopes for better transplant outcome and graft function. Asian J Anim Vet Adv 2011; 6: 1019-1025.

26. Menichini F, Tundis R, Loizzo MR, Bonesi M, Liu Bo, Jones Peter, Persaud SJ, Mastellone V, Lombardi P, Houghton PJ, Avallone L, Menichini F. C. medica cv Diamante peel chemical composition and influence on glucose homeostasis and metabolic parameters. Food Chemistry 2011; 124: 1083-1089.

27. Patil SB, Ghadyale VA, Taklikar SS, Kulkarni CR, Arvindekar AU. Insulin secretagogue, alpha- 
glucosidase and antioxidant activity of some selected spices in streptozotocin-induced diabetic rats. Plant Foods Hum Nutr 2011; 66: 85-90.

28. Tong XL, Song J, Zhao LH, Ji HY. Kaiyuqingre formula improves insulin secretion via regulating uncoupling protein-2 and KATP channel. Chin Med J (Engl) 2011; 124: 2746-2750.

29. Frankish N, Menezes FDS, Mills C, Sheridan H. Enhancement of insulin release from the $\beta$-cell line INS-1 by an ethanolic extract of Bauhinia variegata and its major constituent roseoside. Planta Med 2010; 76: 995-997.

30. Si MM, Lou JS, Zhou CX, Shen JN, Wu HH, Yang $\mathrm{B}, \mathrm{He} \mathrm{QJ}, \mathrm{Wu}$ HS. Insulin releasing and alphaglucosidase inhibitory activity of ethyl acetate fraction of Acoruscalamus in vitro and in vivo. $\mathrm{J}$ Ethnopharmacol 2010; 128:154-159.

31. Smirin P, Taler D, Abitbol G, Brutman-Barazani T, Kerem Z, Sampson SR, Rosenzweig T. Sarcopoteriumspinosum extract as an antidiabetic agent: in vitro and in vivo study. J Ethnopharmacol 2010; 129: 10-17.

32. Fu Z, Liu D. Long-term exposure to genistein improves insulin secretory function of pancreatic $\beta$ cells. Eur J Pharmacol 2009; 616: 321-327.

33. Kawano A, Nakamura H, Hata SI, Minakawa M, Miura Y, Yagasaki K. Hypoglycemic effect of aspalathin, a rooibos tea component from Aspalathuslinearis, in type 2 diabetic model $\mathrm{db} / \mathrm{db}$ mice. Phytomedicine 2009; 16: 437-443.

34. Leu YL, Chen YW, Yang CY, Huang CF, Lin GH, Tsai KS, Yang RS, Liu SH. Extract isolated from Angelica hirsutiflora with insulin secretagogue activity. J Ethnopharmacol 2009; 123: 208-212.

35. Mohseni Salehi Monfared SS, Pournourmohammadi S. Teucriumpolium complex with molybdate enhancecultured islets secretory function. Biol Trace Elem Res 2010; 133: 236-241.

36. Benhaddou-Andaloussi A, Martineau LC, Spoor D, Vuong T, Leduc C, Joly E, Burt A, Meddah B, Settaf A, Arnason JT, Prentki M, Haddad PS. Antidiabetic activity of Nigella sativa seed extract in cultured pancreatic $\beta$-cells, skeletal muscle cells, and adipocytes. Pharm Biol 2008; 46: 96-104.

37. Abudula R, Matchkov VV, Jeppesen PB, Nilsson $\mathrm{H}$, Aalkjaer C, Hermansen K. Rebaudioside A directly stimulates insulin secretion from pancreatic beta cells: a glucose-dependent action via inhibition of ATP-sensitive $\mathrm{K}^{+}$-channels. Diabetes Obes Metab 2008; 10: 1074-1085.

38. Chan JYW, Leung PC, Che CT, Fung KP. Protective effects of an herbal formulation of Radix Astragali, Radix Codonopsis and Cortex Lycii on streptozotocin-induced apoptosis in pancreatic $\beta$ cells: an implication for its treatment of diabetes mellitus. Phytother Res 2008; 22: 190-196.
39. Chen CC, Hsu CY, Chen CY, Liu HK. Fructus Corni suppresses hepatic gluconeogenesis related gene transcription, enhances glucose responsiveness of pancreatic beta-cells, and prevents toxin induced beta-cell death. $\mathrm{J}$ Ethnopharmacol 2008; 117: 483-490.

40. Kanitkar M, Bhonde RR. Curcumin treatment enhances islet recovery by induction of heat shock response proteins, Hsp70 and heme oxygenase-1, during cryopreservation. Life Sci 2008; 82:182189.

41. Kim K, Kim HY. Korean red ginseng stimulates insulin release from isolated rat pancreatic islets. $\mathrm{J}$ Ethnopharmacol 2008; 120: 190-195.

42. Lin E, Wang Y, Mehendale S, Sun S, Wang CZ, Xie JT, Aung HH, Yuan CS. Antioxidant protection by American Ginseng in pancreatic $\beta$ Cells. Am J Chin Med 2008; 36: 981-988.

43. Lv N, Song MY, Kim EK, Park JW, Kwon KB, Park BH. Guggulsterone, a plant sterol, inhibits NF-KB activation and protects pancreatic cells from cytokine toxicity. Mol Cell Endocrinol 2008; 289: 49-59.

44. Menegazzi M, Novelli M, Beffy P, D'Aleo V, Tedeschi E, Lupi R, Zoratti E, Marchetti P, Suzuki H, Masiello P. Protective effects of St. John's wort extract and its component hyperforin against cytokine-induced cytotoxicity in a pancreatic $\beta$-cell line. Int J Biochem Cell Biol 2008; 40: 1509-1521.

45. Park SM, Hong SM, Sung SR, Lee JE, Kwon DY. Extracts of Rehmanniae radix, Ginseng radix and Scutellariae radix improve glucose-stimulated insulin secretion and beta-cell proliferation through IRS2 induction. Genes Nutr 2008; 2: 347-351.

46. Pournourmohammadi S, Sharififar F, Talebiyan E, Khayatian M, Rezazadeh SHA, Moslehi AH. Effect of olive leaf (Oleaeuropaea L.) on glucosestimulated insulin secretion from isolated pancreatic islets of rat. J Med Plants 2008; 28: 3846.

47. Teodoro T, Zhang L, Alexander T, Yue J, Vranic M, Volchuk A. Oleanolic acid enhances insulin secretion in pancreatic beta-cells. FEBS Lett 2008; 582: 1375-1380.

48. Tousch D, Lajoix AD, Hosy E, Azay-Milhau J, Ferrare K, Jahannault C, Cros G, Petit P. Chicoric acid, a new compound able to enhance insulin release and glucose uptake. Biochem Biophys Res Commun 2008; 377: 131-135.

49. Wang ZQ, Lu FE, SLeng H, Fang XS, Chen G, Wang ZS, Dong LP, Yan ZQ. Facilitating effects of berberine on rat pancreatic islets through modulating hepatic nuclear factor 4 alpha expression and glucokinase activity. World $\mathrm{J}$ Gastroenterol 2008; 14: 6004-6011. 
50. Chen WP, Chi TC, Chuang LM, Su MJ. Resveratrol enhances insulin secretion by blocking KATP and KV channels of beta cells. Eur J Pharmacol 2007; 568: 269-277.

51. Dixit PP, Devasagayam TP, Ghaskadbi S. Formulated antidiabetic preparation Syndrex has a strong antioxidant activity. Eur J Pharmacol 2008; 581: 216-225.

52. Govindarajan R, Asare-Anane H, Persaud S, Jones $\mathrm{P}$, Houghton PJ. Effect of Desmodium gangeticum extract on blood glucose in rats and on insulin secretion in vitro. Planta Med 2007; 73:427-432.

53. Hannan JM, Marenah L, Ali L, Rokeya B, Flatt PR, Abdel-Wahab YH. Insulin secretory actions of extracts of Asparagus racemosus root in perfused pancreas, isolated islets and clonal pancreatic betacells. J Endocrinol 2007; 192: 159-168.

54. Hara Y, Fujino M, Takeuchi M, Li XK. Green-tea polyphenol (-)-epigallocatechin-3-gallate provides resistance to apoptosis in isolated islets. J Hepatobiliary Pancreat Surg 2007; 14: 493-497.

55. Kim EK, Kwon KB, Song MY, Han MJ, Lee JH, Lee YR, et al. Flavonoids protect against cytokineinduced pancreatic $\beta$-cell damage through suppression of nuclear factor $\mathrm{KB}$ activation. Pancreas 2007; 35: e1-e9.

56. Kim EK, Kwon KB, Song MY, Seo SW, Park SJ, Ka SO, Na L, Kim KA, Ryu DG, So HS, Park R, Park JW, Park BH. Genistein protects pancreatic cells against cytokine-mediated toxicity. Mol Cell Endocrinol 2007; 278: 18-28.

57. Kim EK, Kwon KB, Han MJ, Song MY, Lee JH, Lv N, Ka SO, Yeom SR, Kwon YD, Ryu DG, Kim KS, Park JW, Park R, Park BH. Coptidis rhizoma extract protects against cytokine-induced death of pancreatic $\beta$-cells through suppression of NF-KB activation. Exp Mol Med 2007; 39: 149-159.

58. Meghana K, Sanjeev G, Ramesh B. Curcumin prevents streptozotocin-induced islet damage by scavenging free radicals: A prophylactic and protective role. Eur J Pharmacol 2007; 577: 183191.

59. Murali YK, Anand P, TandonV, Singh R, Chandra R, Murthy PS. Long-term effects of Terminalia chebula Retz. on hyperglycemia and associated hyperlipidemia, tissue glycogen content and in vitro release of insulin in streptozotocin induced diabetic rats. Exp Clin Endocrinol Diabetes 2007; 115: 641646.

60. Hannan JM, Marenah L, Ali L, Rokeya B, Flatt PR, Abdel-Wahab YH. Ocimum sanctum leaf extracts stimulate insulin secretion from perfused pancreas, isolated islets and clonal pancreatic beta-cells. J Endocrinol 2006; 189: 127-136.

61. Sharma SB, Nasir A, Prabhu KM, Murthy PS. Antihyperglycemic effect of the fruit-pulp of
Eugenia jambolana in experimental diabetes mellitus. J Ethnopharmacol 2006; 104: 367-373.

62. Xiong FL, Sun XH, Gan L, Yang XL, Xu HB. Puerarin protects rat pancreatic islets from damage by hydrogen peroxide. Eur J Pharmacol 2006; 529: 1-7.

63. Yibchok-anun S, Adisakwattana S, Yao CY, Sangvanich P, Roengsumran S, Hsu WH. Slow acting protein extract from fruit pulp of Momordicacharantia with insulin secretagogue and insulinomimetic activities. Biol Pharm Bull 2006; 29:1126-1131.

64. Zhang CY, Parton LE, Ye CP, Krauss S, Shen R, Lin CT, Porco JA Jr, Lowell BB. Genipin inhibits UCP2-mediated proton leak and acutely reverses obesity- and high glucose-induced $b$ cell dysfunction in isolated pancreatic islets. Cell Metab 2006; 3: 417-427.

65. Kwon KB, Kim EK, Lim JG, Shin BC, Han SC, Song BK, Kim KS, Seo EA, Ryu DG. Protective effect of Coptidis Rhizoma on S-nitroso-Nacetylpenicillamine (SNAP)-induced apoptosis and necrosis in pancreatic RINm5F cells. Life Sci 2005; 76: 917-929.

66. Abudula R, Jeppesen PB, Rolfsen SED, Xiao J, Hermansen K. Rebaudioside a potently stimulates insulin secretion from isolated mouse islets: studies on the dose-, glucose-, and calcium-dependency. Metabolism 2004; 53: 1378-1381.

67. Esmaeili MA, Yazdanparast R. Hypoglycemic effect of Teucrium polium: studies with rat pancreatic islets. J Ethnopharmacol 2004; 95: 2730.

68. Hoa NK, Phan DV, Thuan ND, Ostenson CG. Insulin secretion is stimulated by ethanol extract of Anemarrhena asphodeloides in isolated islet of healthy Wistar and diabetic Goto-Kakizaki Rats. Exp Clin Endocrinol Diabetes 2004; 112: 520-525.

69. Norberg A, Hoa NK, Liepinsh E, Van Phan D, Thuan ND, Jörnvall H, Sillard R, Ostenson CG. A novel insulin-releasing substance, phanoside, from the plant Gynostemmapentaphyllum. J Biol Chem 2004; 279: 41361-41367.

70. Rchid H, Chevassus H, Nmila R, Guiral C, Petit P, Chokaïri M, Sauvaire Y. Nigella sativa seed extracts enhance glucose-induced insulin release from rat-isolated Langerhans islets. Fundam Clin Pharmacol 2004; 18: 525-529.

71. Farzami B, Ahmadvand D, Vardasbi S, Majin FJ, Khaghani Sh. Induction of insulin secretion by a component of Urtica dioica leave extract in perifused Islets of Langerhans and its in vivo effects in normal and streptozotocin diabetic rats. J Ethnopharmacol 2003; 89: 47-53.

72. Tabit CE, Chung WB, Hamburg NM, Vita JA. Endothelial dysfunction in diabetes mellitus: 
Molecular mechanisms and clinical implications. Rev Endocr Metab Disord 2010; 11: 61-74.

73. Lenzen, S., Tiedge, M., Jorns, A., Munday, R., Alloxan derivatives as a tool for the elucidation of the mechanism of the diabetogenic action of alloxan, In: Shafrir E (eds ), Lessons from Animal Diabetes. Birkhauser, Boston, pp 113-122, 1996.

74. Mythili MD, Vyas R, Akila G, Gunasekaran S. Effect of streptozotocin on the ultrastructure of rat pancreatic islets. Microsc Res Tech 2004; 63: 274281.

75. Szkudelski T. The mechanism of alloxan and streptozotocin action in B cells of the rat pancreas. Physiol Res 2001; 50: 537-546.

76. Vessal A, Hemmati M, Vasei M. Antidiabetic effects of quercetin in streptozocin-induced diabetic rats. Comp Biochem Physiol C Toxicol Pharmacol 2003; 135C: 357-364.

77. Hii CS, Howell SL. Effects of flavonoids on insulin secretion and $45 \mathrm{Ca}^{2+}$ handling in rat islets of Langerhans. J Endocrinol 1985; 107: 1-8.

78. Kim BH, Cho SM, Reddy AM, Kim YS, Min KR, Kim Y. Down-regulatory effect of quercetin gallate on nuclear factor-KB-dependent inducible nitric oxide synthase expression in lipopolysaccharidestimulated macrophages RAW 264.7. Biochem Pharmacol 2005; 69: 1577-1583.

79. Martinez-Florez S, Gutierrez-Fernandez B, Sanchez-Campos S, González-Gallego J, Tuñón MJ. Quercetin attenuates nuclear factor-KB activation and nitric oxide production in interleukin-1 $\beta$-activated rat hepatocytes. J Nutr 2005; 135:1359-1365.

80. Ruiz PA, Haller D. Functional diversity of flavonoids in the inhibition of the proinflammatory NF-KB, IRF, and AKt signaling pathways in murine intestinal epithelial cells. J Nutr 2006; 136: 664-671.

81. Rahimi R, Ghiasi S, Azimi H, Fakhari S, Abdollahi M. A review of the herbal phosphodiesterase inhibitors; Future perspective of new drugs. Cytokine 2010; 49: 123-129.

82. Mohammadi M, Atashpour S, Pourkhalili N, NiliAhmadabadi A, Baeeri M, Mohammadirad A, Hassani S, Nikfar S, Abdollahi M. Comparative improvement in function of isolated rat Langerhans islets by various phosphodiesterase 3,4 and 5 inhibitors. Asian J Anim Vet Adv 2011; 12: 12331240.

83. Lingohr MK, Dickson LM, McCuaig JF, Hugl SR, Twardzik DR, Rhodes CJ. Activation of IRS-2mediated signal transduction by IGF-1, but not TGF- $\alpha$ or EGF, augments pancreatic $\beta$-cell proliferation. Diabetes 2002; 51: 966-976.
84. Ballinger SW. Mitochondrial dysfunction in cardiovascular disease. Free Radic Biol Med 2005; 38, 1278-1295.

85. Muchova, J., Diabetes mellitus and antioxidans, In: Durackova Z, Bergendi L, Carsky J (eds), Free Radicals and Antioxidants in Medicine (II), (in Slovak). SAP, Bratislava, pp 203-232, 1999.

86. Muchova J, Liptakova A, Orszaghova Z, Garaiová I, Tison P, Cársky J, Duracková Z. Antioxidant systems in polymorphonuclear leukocytes of type 2 diabetes mellitus. Diabet Med 1999; 16: 74-78.

87. Abdollahi M, Ranjbar A, Shadnia S, Nikfar S, Rezaie A. Pesticides and oxidative stress: a review. Med Sci Monit 2004; 10: RA 144-RA 147.

88. Durackova, Z., Oxidants, antioxidants and oxidative stress, In: Gvozdjakova A (eds), Mitochondrial Medicine: Mitochondrial Metabolism, Diseases, Diagnosis and Therapy. Springer, Amsterdam, pp 19-49, 2008.

89. Knott AB, Bossy-Wetzel E. Nitric oxide in health and disease of the nervous system. Antioxid Redox Signal 2009; 11: 541-553.

90. Kim F, Gallis B, Corson MA. TNF-alpha inhibits flow and insulin signaling leading to NO production in aortic endothelial cells. Am J Physiol Cell Physiol 2001; 280: C1057-1065.

91. Bierhaus A, Chevion S, Chevion M, Hofmann M, Quehenberger P, Illmer T, Luther T, Berentshtein E, Tritschler H, Müller M, Wahl P, Ziegler R, Nawroth PP. Advanced glycation end productinduced activation of NF-kappa B is suppressed by alpha-lipoic acid in cultured endothelial cells. Diabetes 1997; 46: 1481-1490.

92. Bierhaus A, Schiekofer S, Schwaninger M, Andrassy M, Humpert PM, Chen J, Hong M, Luther T, Henle T, Klöting I, Morcos M, Hofmann M, Tritschler H, Weigle B, Kasper M, Smith M, Perry G, Schmidt AM, Stern DM, Häring HU, Schleicher E, Nawroth PP. Diabetes-associated sustained activation of the transcription factor nuclear factor-kappaB. Diabetes 2001; 50: 27922808.

93. Kim F, Tysseling KA, Rice J, Pham M, Haji L, Gallis BM, Baas AS, Paramsothy P, Giachelli CM, Corson MA, Raines EW. Free fatty acid impairment of nitric oxide production in endothelial cells is mediated by IKKbeta. Arterioscler Thromb Vasc Biol 2005; 25: 989-994.

94. Kim F, Pham M, Maloney E, Rizzo NO, Morton GJ, Wisse BE, Kirk EA, Chait A, Schwartz MW. Vascular inflammation, insulin resistance, and reduced nitric oxide production precede the onset of peripheral insulin resistance. Arterioscler Thromb Vasc Biol 2008; 28: 1982-1988.

95. Ranjbar S, Larijani B, Abdollahi M. Recent update on animal and human evidences of promising 
antidiabetic medicinal plants: a mini-review of targeting new drugs. Asian J Anim Vet Adv 2011; 6: 1271-1275.

96. Mohseni-Salehi-Monfared SS, Larijani B, Abdollahi M. Islet transplantation and antioxidant management: A comprehensive review. World J Gastroenterol 2009; 15: 1153-1161.

97. Hosseini A, Abdollahi M. It is time to formulate an antioxidant mixture for management of diabetes and its complications: notice for phannaceutical industries. Int J Pharmacol 2012; 8: 60-61.

98. Hosseini A, Abdollahi M. Antioxidants as an appropriate approach to improve the outcome of pancreatic islet isolation: evidences from animal studies. Asian J Anim Vet Adv 2012; 7: 540-541.

99. Momtaz S, Abdollahi M. An update on pharmacology of Satureja species; from antioxidant, antimicrobial, antidiabetes and antihyperlipidemic to reproductive stimulation. Int $\mathrm{J}$ Pharmacol 2010; 6: 454-461.

100. Vosough-Ghanbari S, Rahimi R, Kharabaf S, effects of Satureja khuzestanica on serum glucose, lipids and markers of oxidative stress in patients with type 2 diabetes mellitus: a double-blind randomized controlled trial. Evid Based Complement Alternat Med 2010; 7: 465-470.

101. Mehri A, Hasani-Ranjbar S, Larijani B, Abdollahi M. A systematic review of efficacy and safety of Urtica dioica in the treatment of diabetes. Int $\mathrm{J}$ Pharmacol 2011; 7: 161-170.

102. Hassani-Ranjbar S, Nayebi N, Larijani B, Abdollahi M. A systematic review of the efficacy and safety of Teucrium species; from anti-oxidant to anti-diabetic effects. Int J Pharmacol 2010; 7: 315-325.

103. Pourkhalili N, Pournourmohammadi S, Rahimi F, Vosough-Ghanbari S, Baeeri M, Ostad SN, Abdollahi M. Comparative effects of calcium channel blockers, autonomic nervous system blockers, and free radical scavengers on diazinoninduced hyposecretion of insulin from isolated islets of Langerhans in rats. Arh Hiq Rada Toksikol 2009; 60: 157-164.

104. Lelliott C, Vidal-Puig AJ. Lipotoxicity, an imbalance between lipogenesis de novo and fatty acid oxidation. Int $\mathrm{J}$ Obes Relat Metab Disord 2004; 28: 22-28.

105. Chen PY, Csutora P, Veyna-Burke NA, Marchase RB. Glucose-6-phosphate and $\mathrm{Ca} 2+$ sequestration are mutually enhanced in microsomes from liver, brain, and heart. Diabetes 1998; 47: 874-881.

106. Shapiro AM, Lakey JRT, Ryan EA, Korbutt GS, Toth E, Warnock GL, Kneteman NM, Rajotte RV. Islet transplantation in seven patients with type 1 diabetes mellitus using a glucocorticoid-free immunosuppressive regimen. N Engl J Med 2000; 343: 230-238.

107. Gray H, Williams PL, Bannister LH. Gray's anatomy: the anatomical basis of medicine and surgery. Churchill-Living-stone, New York 1995.

108. Deters NA, Stokes RA, Gunton JE. Islet transplantation: factors in short-term islet survival. Arch Immunol Ther Exp 2011; 59: 421-429.

109. Agrawal A, Gurusamy K, Powis S, Gray DW, Fuller B, Davidson BR. A meta-analysis of the impact of the two-layer method of preservation on human pancreatic islet transplantation. Cell Transplant 2008; 17: 1315-1322.

110. Kaddis JS, Danobeitia JS, Niland JC, Stiller T, Fernandez LA. Multicenter analysis of novel and established variables associated with successful human islet isolation outcomes. Am J Transplant 2010; 10: 646-656.

111. Bataille D. Molecular mechanisms of insulin secretion. Diabetes Metab 2002; 28: 4S7-13.

112. Maechler P. Novel regulation of insulin secretion: the role of mitochondria. Curr Opin Investig Drugs 2003; 4: 1166-1172.

113. Chan CB, De Leo D, Joseph JW, McQuaid TS, Ha $\mathrm{XF}$, Xu F, Tsushima RG, Pennefather PS, Salapatek AM, Wheeler MB. Increased uncoupling protein-2 levels in beta-cells are associated with impaired glucose-stimulated insulin secretion: mechanism of action. Diabetes 2001; 50: 13021310.

114. Kassis N, Bernard C, Pusteria A, Castellia L, Penicaud L, Richard D, Ricquier D, Ktorza A. Correlation between pancreatic islet uncoupling protein-2 (UCP2) mRNA concentration and insulin status in rats. Int J Exp Diabetes Res 2000; 1: 185193.

115. Zhang CY, Baffy G, Perret P, Krauss S, Peroni O, Grujic D, Hagen T, Vidal-Puig AJ, Boss O, Kim YB, Zheng XX, Wheeler MB, Shulman GI, Chan $\mathrm{CB}$, Lowell $\mathrm{BB}$. Uncoupling protein-2 negatively regulates insulin secretion and is a major link between obesity, beta cell dysfunction, and type 2 diabetes. Cell 2001; 105: 745-755.

116. Sasahara M, Nishi M, Kawashima H, Ueda K, Sakagashira S, Furuta H, Matsumoto E, Hanabusa T, Sasaki H, Nanjo K. Uncoupling protein 2 promoter polymorphism -866G/A affects its expression in beta-cells and modulates clinical profiles of Japanese type 2 diabetic patients. Diabetes 2004; 53: 482-485.

117. Sesti G, Cardellini M, Marini MA, Frontoni S, D'Adamo M, Del Guerra S, Lauro D, De Nicolais P, Sbraccia P, Del Prato S, Gambardella S, Federici M, Marchetti P, Lauro R. A common polymorphism in the promoter of UCP2 contributes 
bto the variation in insulin secretion in glucosetolerant subjects. Diabetes 2003; 52: 1280-1283.

118. van de Venter M, Roux S, Bungu LC, Louw J, Crouch NR, Grace OM, Maharaj V, Pillay P, Sewnarian P, Bhagwandin N, Folb P. Antidiabetic screening and scoring of 11 plants traditionally used in South Africa. J Ethnopharmacol 2008; 119: 81-86
119. Mostafalou S, Abdollahi M. The role of environmental pollution of pesticides in human diabetes. Int J Pharmacol 2012;8: 139-140. 
Table1. In vitro studies in assessment of herbal and natural products on insulin secretion of pancreatic islets

\section{Herbal/components}

\section{Sample Study design}

flavonol, flavan, diphenyl

propane
Non-

diabetic rat

$\begin{array}{ll}\begin{array}{l}\text { Isoprenylated flavan } \\ \text { (Kazinol U)/ 30, 60 }\end{array} & \begin{array}{l}\text { Non- } \\ \text { diabetic rat }\end{array} \\ \mu \mathrm{m} & \end{array}$

$\mu \mathrm{m}$
Pretreated RINm5F cells

and isolated islet cells

with/without the

substance and then

treated with cytokines

\section{Saururus Chinensis baill.} (saururaceae)/------

Non-

diabetic rat

Pretreated RINm5F cells and isolated islet cells

\section{Lignan}

(phytoesterogen) /20,

$40 \mu \mathrm{m}$ with/without the substance and then treated with cytokines

Galactolipid,

flavonoid, selenium, urea/0. 1, 1, 10, 100, 1000 ppm

Tanacetumvulgare, Urtica dioica/ multi herbal

\section{Non- \\ diabetic rat \\ Incubated isolated islet \\ cells with/without \\ different concentrations \\ of the substances}

\section{Plant extract/1-24}

$\mathrm{mg} / \mathrm{ml}$

Diamante/flavonoid,

flavanone

Myristica fragrans (M. F), Parmelia perlata (P. P),

Illicium verum (I. V),

Trachyspermum copticum

(T. C), Myristica

\section{Gallic acid, flavonoid/ $100,200 \mathrm{mg} / \mathrm{kg}$ of each plant}

mouse

Diabetic Incubated isolated islet

(T2DM) rat cells with/without the

substances vs. $1.6 \mathrm{mg} / \mathrm{kg}$ BW gliclazide as positive control, or non-diabetics,
Duration Outcomes

diabretic with/without plant extract

$48 \mathrm{~h}$

$$
\begin{aligned}
& \text { Dose-dependent increase in viability of } \\
& \text { RINm5F cells, decrease in NO production, } \\
& \text { and iNOS expression, marked suppression of } \\
& \text { NF- } \mathrm{B} \text {, decrease in } \mathrm{H}_{2} \mathrm{O}_{2} \text { production, } \\
& \text { effective prevention of caspase activation and } \\
& \text { PARP cleavage, dose-dependent recovery of } \\
& \text { cytokine-impaired insulin secretion close to }
\end{aligned}
$$
that of the control

Dose-dependent increase in viability of RINm5F cells, dose-dependent decrease in NO production, and iNOS expression, marked suppression of NF- $\kappa \mathrm{B}$, decrease in JAK/STAT, dose-dependent recovery of cytokine-impaired GSIS close to that of the control

$24 \mathrm{~h}$ Increaseed viability maximum at $1 \mathrm{ppm}$, increase in basal insulin secretion and GSIS at $0.1 \mathrm{ppm}$, marginal increase in basal insulin secretion and GSIS at $1 \mathrm{ppm}$, decrease in basal insulin secretion and GSIS at10, 100, $1000 \mathrm{ppm}$, decrease in ROS at $0.1 \mu \mathrm{m}$

$3 \mathrm{~h} \quad$ Suppression of $\alpha$-amylase and $\alpha$-glucosidase vs. acarbose, dose-dependent increase in GSIS

Ref.

$24 \mathrm{~h}$ Dose-dependent increase in insulin secretion by M. F, T. C, M. M, increase in antioxidants activity vs. ascorbic acid as positive control, increase in $\alpha$-glucosidase inhibitor in P. P, M. M, M. F, T. C vs. positive 
malabarica (M. M)/ multi herbal

Berberine, rhubarb, peony root, bupleurum, coptis, root of herbaceous peony (named Kaiyuqinngre formula [KYQRF])/

Bauhinia variegate/ fatty acid, protein, terpene, alkaloid, steroid, flavonoid

Acoruscalamus L. $(A C) / \alpha$ and $\beta$-asarone, eugenol

Sarcopoterium spinosum (SS)/ triterpenoid, catechin, epicatechin

Plant extract (SSE)/0. Non001-10 mg/ml diabetic

and roseoside(R)/ 50, $250,500 \mathrm{ng} / \mathrm{ml}$ of EE, 1. $25,2.5,5 \mathrm{ng} / \mathrm{ml}$ of $\mathrm{R}$

AC or ethyl acetate fraction of $\mathrm{AC}(\mathrm{ACE}) /$ $6.25,12.5,25 \mu \mathrm{g} / \mathrm{ml}$ mouse diabetic mouse

or diabetics as control

Incubated INS- 1 cells

with different

concentration of KYQRF

vs. control or $10 \mu \mathrm{mol} / 1$ of rosiglitazone

Incubated INS-1 cells with different

concentration of $\mathrm{EE}$ or $\mathrm{R}$

vs. $25,50,100 \mathrm{nM}$

glibenclamide or DMSO as control

Incubated HIT-T15 cells with different

concentration of $\mathrm{AC}$ or one of its four fractions vs. gliclazide or negative control

Incubated RINm cells, L6 myotubes, 3T3-L1

adipocytes and AML-12 hepatocytes with/without SSE

Incubated INS-1 E cells, freshly isolated islet cells diabetic mouse, nonwith/without the

diabetic substance vs. similar doses of vehicle
$48 \mathrm{~h}$

Increaseed viability in high dose vs. rosiglitazone, increase in GSIS at middle dose of KYQRF vs. rosiglitazone, marked suppression of UCP2 and sulfonylurea receptor 1 with all doses of KYQRF and rosiglitazone vs. control

Dose-dependent increase in GSIS by EE and $\mathrm{R}$ vs. DMSO, increase in GSIS by EE vs. $\mathrm{R}$

Increase in insulin secretion in $\mathrm{AC}(6.25,12.5$ $\mu \mathrm{g} / \mathrm{ml})$, and $\operatorname{ACE}(6.25,12.5,25 \mu \mathrm{g} / \mathrm{ml}) \mathrm{vs}$. negative control close to that of the gliclazide, dose-dependent inhibition of $\alpha$-glucosidase activity

Increase in basal insulin secretion in RINm at $0.1 \mathrm{mg} / \mathrm{ml}$ of SSE, increase in glucose / forskolin-induced insulin secretion in RINm at $0.001,0.01,0.1 \mathrm{mg} / \mathrm{ml}$ of SSE vs. control, increase in viability, suppression of lipolysis in adipocytes, induce glucose uptake in adipocytes, hepatocytes and myotubes, increase in glycogen synthesis in myotubes

Dose-dependent increase in GSIS independent of PTK, marginal effect on basal or highglucose stimulated ATP production, increase in sodium pyruvate-stimulated insulin secretion, dose-dependent increase in Kclstimulated insulin secretion vs. induced high glucose or pyruvate, potentiation of glucose 


\section{Rooibos \\ (AspalathusLinearis)/}

polyphenole, flavonoid,

non-flavonoid

Angelica hirsutiflora/------

Teucrium poliuml (TP)/

diterpene derivative, fatty

acid ester, flavonoid, steroid

\section{Nigella sativa L (NS) \\ volatile oil, fixed oil}

Cultured INS832/13 cells,

Stevia rebaudianaBertoni (SrB)/ steviol, stevioside, glucoside

Astragalus membranaceus Bge, Codonopsis pilosula Nannf, Lycium chinense Mill. / ---------

Cornus officinalis Sieb. carboxylic alcohol, four molecules of Dglucose (Rebaudioside

$$
\text { A) } / 10^{-13}-10^{-7} \mathrm{M}
$$

Water extract (linoleic Nonacid, astragaloside IV) diabetic /

$$
0.78-100 \mu \mathrm{g} / \mathrm{ml}
$$

Methanol extract, Non- Incubated alloxan,

\section{Flavonoid \\ (Aspalathin) /1-100 \\ $\mu \mathrm{M}$}

Plant extract/ 50-150 $\mu \mathrm{g} / \mathrm{ml}$

$\mathrm{TP} / 0.01,0.1 \mathrm{mg} / \mathrm{mL}$ with/without $1 \mathrm{mM}$

sodium molybdate or sodium orthovanadate

Crude ethanol extract/ $200 \mu \mathrm{g} / \mathrm{ml}$
Diabetic

(T2DM)

mouse

Non-

diabetic

mouse,

non-

diabetic

human

Non-

diabetic rat

Cultured islet cells with each or combination of these substances

Nondiabetic rat $\beta$-TC-tet cells,

Incubated RIN-m5F cells

Cultured isolated islet without the
Steviol, diterpenic

induced increase in intracellular $\mathrm{Ca}^{2+}$ concentration of INS-1E cells differentiated skeletal muscle cells, and adipocytes with/ without the substance vs. $10 \mu \mathrm{m}$ rosiglitazone

Incubated isolated MIN6 cells with/without the substance

Incubated cultured RINm5F cells with/without the substances
Increase in GSIS, increase in

$\beta$-cell proliferation vs. vehicle, increase in basal glucose uptake in muscle cell and adipocytes, increase in triglyceride accumulation in pre-adipocytes vs. rosiglitazone

Dose-, glucose- and $\mathrm{Ca}^{2+}$ dependent increase in insulin secretion, increase in ATP/ADP ratio without change in intracellular cAMP level, glucose-dependent decrease in KATP sensitive channel conduction

$24 \mathrm{~h}$ Increase in viability maximum at $25 \mu \mathrm{g} / \mathrm{ml}$, decrease in apoptosis at $25 \mu \mathrm{g} / \mathrm{ml}$, dosedependent decrease in iNOS until $25 \mu \mathrm{g} / \mathrm{ml}$, decrease in expression of apoptosis-related proteins 
etZucc. /ursolic acid, oleanolic acid, loganin, phenolic compounds

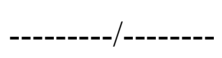

ginseng/ginsenoside, acidic polysaccharide, protein, phenolic

\section{American ginseng berry/ginsenoside, saponin, flavonoid, triterpenoid}

\section{Commiphoramukul/}

Hypericum perforatum (St. John'swort) (SJW)/ naphtodianthron,

phloroglucinol, melatonin, flavonoid, phenolic acid fraction $/ 25 \mathrm{mg} / \mathrm{ml}$

diabetic rat

cytokine or STZ-treated BRIN-BD11 cells with/without the substances

Curcumin/ $10 \mu \mathrm{m} / \mathrm{L}$

Non-

diabetic rat

Cryopreservation of cultured isolated islet cells with/ without curcumin

Ginsenoside / 0. 05-1. Non-

$0 \mathrm{mg} / \mathrm{ml}$ cells with ginsenoside

\section{Berry extract and}

Nonginsenosid Re/ 0. 1, 0 .

$5,1.0 \mathrm{mg} / \mathrm{ml}$ of berry extract, $0.05,0.1$ $\mathrm{mg} / \mathrm{ml}$ of ginsenosid Re

\section{Cis- and trans-}

Nonguggulsterone/ 12.5, diabetic rat $25 \mu \mathrm{M}$

SJW extract or hyperforine (HPF)/ 25 $\mu \mathrm{g} /$ different

concentrations for different assay
Non-

diabetic

rat, non-

diabetic

human
Incubated MIN-6 cells with/without the substances and assess their response to $\mathrm{H}_{2} \mathrm{O}_{2}$

Pretreatment cultured islet cells with/ without guggulsterone and then treatment with cytokines

Incubated INS-1 E cells and isolated islet cells with cytokine and with/without SJW or HPF

insulin mimic activity on PEPCK expression, increase in GSIS, increase in total cell mass of H4IIE or BRIN-BD11 with fraction starting from 12.5 or $6.125 \mu \mathrm{g} / \mathrm{ml}$, protection ofBRIN-BD11 against toxicity from cytokines or STZ starting from 12.5 or $6.25 \mu \mathrm{g} / \mathrm{m}$

$10 \mathrm{~d}$

Increase in viability, increase in insulin secretion vs. non-treated but similar to fresh isolated islets, decrease in ROS vs. non treatment non-treated, increase in level of Hsp70 and HO-1

$2 \mathrm{~h}$

Insulinotropic effect dependent on influx of $\mathrm{Ca}^{2+}$ and KATP channel blockade but independent of glucose

$10 \mathrm{~min}$ acute, 48 $\mathrm{h}$ chronic

Decrease in oxidant injury in acute and chronic conditions, dose-dependent increase in insulin secretion

Decrease in cytokine-mediated cytotoxicity, decrease in NO and PGE2 production, decrease in iNOS, decrease in COX-2 mRNA and protein expression, decrease in JAK/STAT activation, decrease in $\mathrm{NF}-\mathrm{\kappa B}$ activation, decrease in down regulation of SOCS-3, restoration of insulin secretion on islet cell close to that of control

$20 \mathrm{~h} \quad$ Suppression of cytokine- impaired in GSIS at $25 \mu \mathrm{g} / \mathrm{ml} \mathrm{SJW}$ or $1 \mu \mathrm{M}$ HPF, dose-dependent decrease in apoptosis at $6.25-50 \mu \mathrm{g} / \mathrm{ml} \mathrm{SJW}$ or $0.5-3 \mu \mathrm{g} / \mathrm{ml} \mathrm{HPF}$, dose-dependent decrease in iNOS at $10-100 \mu \mathrm{g} / \mathrm{ml} \mathrm{SJW}$ or $0.25-2 \mu \mathrm{M}$ HPF, decrease in cytokine-induced STAT-1 at $10-50 \mu \mathrm{g} / \mathrm{ml} \mathrm{SJW}$ or $2 \mu \mathrm{M}$ HPF, dose- 
Rehmanniae radix, Ginseng radix, Scutellariae radix/--

Unknown $/ 50 \mu \mathrm{g} / \mathrm{ml}$

Unknown/0. 01, 0. 05, $0.1,1 \mathrm{mg} / \mathrm{ml}$ phenolic constituents, squalene

\section{Unknown/.....}

Cichorium intybus/ phenolic compound, aesculetin, aesculin, cichoriin, glycoside

Rhizoma coptidis/ alkaloid, non-alkaloid

Plant-derived triterpenoid (Oleanolic acid) $/ 30,50 \mu \mathrm{M}$ vs.

$100,200 \mu \mathrm{m}$

tolbutamide, or $50 \mathrm{~nm}$

exendin-4

Mono-caffeoyl ester (CGA) and dicaffeoyl $100 \mu \mathrm{g} / \mathrm{ml}$

Isoquinoline alkaloid (Berberine) $/ 1,3,10$,
Non- Incubated isolated islet

diabetic rat cells with vehicle or each herbal extract or $2.5 \mathrm{nM}$

exendin-4 as positive control

Incubated isolated islet cells with/without the substance ester (CRA)/10, 50, $30 \mu \mathrm{mol} / 1$

Non-

diabetic rat

Non-

diabetic rat isolated islet cells

with/without the

substance

\section{Non-}

diabetic rat

Incubated INS-1E cells

and islet cells with

CRA or CGA

Non-

diabetic rat

Incubated isolated islet

cells with different

concentration of the
Incubated INS-1 cells and

glucose and with/ without

substance vs. $1 \mu \mathrm{mol} / 1$

glibenclamide or without

them

\section{Polyphenol \\ (Resveratrol) /3- \\ $100 \mu \mathrm{mol} / 1$} mouse and RIN-m5F cells with dependent decrease in NF $\kappa$ B activation at $25-100 \mu \mathrm{g} / \mathrm{ml} \mathrm{SJW}$ or $1-10 \mu \mathrm{M}$ HPF

$24 \mathrm{~h}$ Increase in GSIS by plants but lower than level achieved with exendin-4, increase in IRS2, PDX-1 and GK mRNA, promote $\beta$ cellproliferation, increase in viability, insulinotropic agent like exendin-4

$0.5 \mathrm{~h}$ Increase in basal insulin secretion at 0.05 $\mathrm{mg} / \mathrm{ml}$, marginal increase in GSIS

Increaseed basal insulin secretion and GSIS in INS-1 at maximum $50 \mu \mathrm{M}$ vs. tolbutamide but similar to exendin-4, increase in insulin secretion in GSIS at $30 \mu \mathrm{M}$, increase in total cellular insulin protein, increase in mRNA level, increase in glucagon and somatostatin,

$1.5 \mathrm{~h}$ Increase in insulin-induced glucose uptake at $100 \mu \mathrm{g} / \mathrm{ml} \mathrm{CRA}$ or CGA and in presence of insulin, increase in GSIS at 10, $50 \mu \mathrm{g} / \mathrm{ml} \mathrm{CRA}$ or CGA in INS-1E, increase in GSIS at 50 $\mu \mathrm{g} / \mathrm{ml} \mathrm{CRA}$ or CGA in islet cells

$24 \mathrm{~h}$ Dose-dependent increase in GSIS vs. control except at $30 \mu \mathrm{mol} / 1$, increase in viability, increase in GK activity at 3, 10, $30 \mu \mathrm{mol} / 1 \mathrm{vs}$. glibenclamide or control, cytotoxicity on islet cells at $30 \mu \mathrm{mol} / 1$, dose- dependent up regulation of HNF4- $\alpha$ mRNA expression with maximum effect at $10 \mu \mathrm{mol} / 1 \mathrm{vs}$.

glibenclamide or control

$1 \mathrm{~h} \quad$ Dose-dependent suppression of ATP-sensitive $\mathrm{K}^{+}$channel vs. control, suppression of voltagegated $\mathrm{K}^{+}$channel vs. control at concentration higher than $30 \mu \mathrm{mol} / 1$, increase in insulin secretion in all doses in RIN-m5F and Hit-T15 no effect on intracellular $\mathrm{Ca}^{2+}$

diabetic MIN6cells, Hit-T15 cells, /without the substances vs. $30,100 \mu \mathrm{mol} / 1$ 
Germinated fenugreek (Trigonella foenumgr aecum)/ phenolic, flavonoid

Powder of plant (S1), boiled aq (S2), soxhlet fractions (petroleum ether (E1), chloroform (E2), methanol (E3), aqueous soxhlet extract (E4))/ doses of S1, or S2: 2. 5, 5, $10 \%$, doses of others: 0. $5,2.5,5 \%$

Desmodium gangeticum (GD)/flavones, isoflavonoid glycoside

Asparagus racemosus/ flavonoid, amino acid, oligosaccharide, steroidal saponin

Green tea/flavonoid, catechin, epicatechin luteolin/25, $50 \mu \mathrm{M}$

DG extract/0. 25-2 $\mathrm{mg} / \mathrm{ml}$

Dried root (ethanol extract), or plant fractions (heaxane, ethyl acetate, butanol, chloroform, aqueous fraction) $/ 8,40,200$, $1000,5000 \mu \mathrm{g} / \mathrm{ml}$

Epigallocatechin-3gallate $(\mathrm{EGCG}) / 36$, $72,360 \mu \mathrm{m} / 1$

flavonoid

\section{glibenclamide or control}

Incubated isolated islet cells with/without the substances

$\begin{array}{ll}\text { diabetic } & \text { cells with/without the } \\ \text { mouse } & \text { substances }\end{array}$

Diabetic (T2DM) rat

Incubated MIN6 cells with $2 \mathrm{mM}$ glucose and with/without DG

Non- Incubated isolated clonal diabetic rat BRIN-BD11 cells, islet cells, and perfused pancreas with/without the substances

\section{Non-} diabetic rat

Cultured isolated islet cells under normal or hypoxia/reoxygenation (H/R) condition with/without EGCG

Non- Incubated pretreated diabetic RINm5F cells with rat cytokine with/ without the substances vs. control except at $100 \mu \mathrm{mol} / 1$ in MIN6

$48 \mathrm{~h}$ Increase in GSIS and basal insulin secretion, increase in viability, decrease in MDA, protein carbonyls, ROS in STZ treated, highest antioxidant activity in E3, highest protection against lipid peroxidation in E3, marginal change in uric acid or glutathione, decrease in GR, SOD and increase in CAT, GPx in STZ treated

Increase in basal and GSIS in islet cells with all substances except aqueous fraction, increase in basal and GSIS in perfused pancreas with all substances except butanol and aqueous fraction, increase in basal and GSIS in BRIN-BD11 with all substances except heaxane for basal insulin and ethyl acetate for GSIS, $\mathrm{Ca}^{2+}$-dependent increase in insulin secretion in BRIN-BD11 with all substances except ethyl acetate and butanol fractions

$48 \mathrm{~h}$ Dose-dependent decrease in apoptosis, decrease in $\mathrm{LDH}$, protection against decline of insulin secretion

Dose-dependent increase in viability, suppression of cytokine-mediated cytotoxicity, decrease in NO production and iNOS expression, dose-dependent decrease in 
Soybean/ isoflavone

Rhizoma Coptidis/ alkaloid, non-alkaloid

Curcuma longa (Turmeric)/ curcuminoid, volatile oil

sugar, protein, resin
Genistein/ 5, 10, 20, $40 \mu \mathrm{M}$

Plant extract/ 5, 10 , $20,50 \mu \mathrm{g} / \mathrm{ml}$

Curcumin $/ 10 \mu \mathrm{M}$ vs. vehicle

Aqueous extract of TC / $200 \mu \mathrm{l}(2 \mathrm{mg} / \mathrm{ml})$ for

(TC)/gallic acid, luteolin,

tannic acid, chebulinic acid

Ocium sanctum/ oleanolic acid, ursolic acid, rosmarinic acid, eugenol, carvacrol, linalool, $\beta$ caryophyllene, $\beta$-elemene, $\beta$-caryophyllene, germacrene D

Ethanol extract, aqueous, butanol, ethylacetate fractions/ dose of perfustation 1 $\mathrm{mg} / \mathrm{min}$, dose for clonal $\beta$-cells 8-5000 $\mu \mathrm{g} / \mathrm{ml}$
Nondiabetic rat

Incubated cultured $\beta$-cells and RINm5F cells with/

without genistein and then treated with cytokine

Nondiabetic rat

Incubated RINm5F cells and isolated islet cells with/ without the substance and then treated with cytokine

Non-

diabetic

mouse

Incubated isolated islet cells with curcumin and then treated with STZ

Incubated islet cells

(T2DM) rat with/without aqueous extract of TC vs.

tolbutamide

Non- Incubated perfused diabetic rat pancreas, isolated islet cells and clonal BRINBD11 cells with/ without different concentration of the substances

NF_ $\kappa B$ activation, marginal preservation of GSIS (at $20 \mathrm{mM}$ glucose) in presence cytokines vs. control

\section{Diabetic}

$48 \mathrm{~h}$

$48 \mathrm{~h}$ Increaseed viability, decrease in NO
Dose-dependent increase in viability, dosedependent decrease in cytokine-induced NO production and iNOS expression, suppression of

ERK-1/2 and JAK/STAT activation, decrease in NF_ $\kappa$ B activation, suppression of MAPK pathway, dose-dependent preservation of GSIS production and iNOS expression, suppression of NF $\kappa \mathrm{B}$ activation, dose-dependent preservation of GSIS

Dose-dependent increase in viability, dosedependent suppression of STZ-induced $\beta$-cell dysfunction, decrease in activated PARP, increase in cu/zn SOD and decrease in MDA, decrease in peroxynitrite and STZ generation of $\mathrm{NO}$, increase in insulin secretion

$2 \mathrm{~h} \quad$ Increase in insulin release vs. untreated diabetics and higher than tolbutamide

$1 \mathrm{~h}$ Increase in insulin secretion by all fractions except hexane and chloroform, increase in intracellular $\mathrm{Ca}^{2+}$ in clonal cells by all substances, decrease in viability at doses higher than $5000 \mu \mathrm{g} / \mathrm{ml}$, increase in insulin secretion at doses higher than $5000 \mu \mathrm{g} / \mathrm{ml}$ by chloroform and hexane partition but concomitant decrease in viability 
Fruit of Eugenia

jambolana/oleanolic acid, ursolic acid, $\beta$-sitosterol, gallic acid

Pueraria lobata/ flavonoid, isoflavonoid

Momordica charantial Steroidal saponin, insulinlike peptide, alkaloid, momordicin, glycoside, terpenoid

Gardenia jasmine ides Ellis/ glycoside, glycoprotein chloregenic acid

Glycoside (genipin)/50 nM, 0 . $5 \mu \mathrm{M}, 5 \mu \mathrm{M}$

Protein extract of fruit/ $10 \mu \mathrm{g} / \mathrm{ml}$

Diabetic

(T2DM) rat incubated $\mathrm{C}_{2} \mathrm{C}_{12}$ myocytes

Non-

diabetic

mouse

(wild-type

(WT) and

UCP2-

deficient

mouse)

Coptidis Rhizoma/ alkaloid, non-alkaloid

\section{Plant extract \\ (CRE)/10, 20, 50 \\ $\mu \mathrm{g} / \mathrm{ml}$}

Non-

Stevia

Rebaudioside A/ $10^{-16}$

Non-

rebaudianaBertoni/glycosid

$-10^{-6} \mathrm{~mol} / 1$

e, stevioside, rebaudioside
Perfused islet cells, and 3T3-L1 adipocytes with/ without the

substance

cells with CRE then

treated with $0.1 \mathrm{mM} \mathrm{S}$ -

nitroso-N-

acetylpenicillamine

(SNAP) vs. control or

SNAP without CRE SOD at $50,100 \mu \mathrm{M}$

Incubated isolated islet cells with/without the substance
$1 \mathrm{~h}$

Increase in release of insulin vs. non-treated diabetics or contro

$48 \mathrm{~h}$

Marginal protection against viability loss from $\mathrm{H}_{2} \mathrm{O}_{2}$ toxicity, suppression of apoptosis at 50 , $100 \mu \mathrm{M}$, dose-dependent increase in basal insulin secretion and GSIS at $100 \mu \mathrm{M}$ vs. $\mathrm{H}_{2} \mathrm{O}_{2}$, dose-dependent decrease in ROS, dosedependent increase in CAT at $100 \mu \mathrm{M}$ and

$18 \mathrm{~h}$ Increase in insulin secretion, increase in glucose uptake in myocytes, increase in glucose uptake in adipocytes

$48 \mathrm{~h} \quad$ Suppression of UCP2-mediated proton leak in isolated mitochondrial, increase in mitochondrial membrane potential, and ATP level concomitant close KATP channels in WT vs. UCP2-deficient, increase in basal insulin secretion at $0.5,5 \mu \mathrm{M}$ in WT, improvement in obesity induced GSIS impairment, dependent effects to iUCP2, suppression of UCP2

Suppression of apoptosis and necrosis, suppression of potential disruption of mitochondrial membrane, no effect on SNAPinduced $\mathrm{NO}$ production, retain in insulin secretion capacity in islets treated IL-1 $\beta$ at 10 , $50 \mu \mathrm{g} / \mathrm{ml} \mathrm{CRE}$

$140 \mathrm{Min} \quad \mathrm{Ca}^{2+}$-and glucose dose-dependent increase in insulin secretion at $10^{-14}-10^{-6} \mathrm{~mol} / 1 \mathrm{vs}$. control 
A

Teucrium polium/

flavonoid, diterpene

derivative, fatty acid ester, steroid

asphodeloides/ glycoside,

saponin, polysaccharide,

norlignan

Gynostemma pentaphyllum/ saponin (gypenosid)

Nigella sativa Linn. (black cumin)/ alkaloid, saponin, fixed oil, essential oil, protein

\section{Anemarrhena}

Crude extract/0. 001-1 mg of plant leaf culture medium

\section{Plant ethanol extract} (TH2) $/ 2,4,8 \mathrm{mg} / \mathrm{ml}$

Diabetic

\section{Gypenosid}

(phanoside)/ 7. 8, 15 .

6, 31. 3, 62. 5, 125,

$250,500 \mu \mathrm{M}$

Different fractions:

defatted fraction (HR

II), acidic and neutral

compounds (HR III),

basic compounds (HR

IV)/ 0. 01, 0. 1, 1, 5

$\mathrm{mg} / \mathrm{ml}$

\section{Urtica dioica/lectin,} polysaccharide, steroid, caffeic malic acid powder $/ \mathrm{ml}$ of the

\section{Different plant fractions of aqueous extract $/ 1 \mathrm{ml}$ \\ Non- \\ diabetic rat \\ Incubated isolated islet cells with/ without the substance}

\section{Diabetic}

(T2DM) rat

Incubated or perfused

isolated islet cells

with/without the

substances

Non- Incubated isolated islet

diabetic rat cells with phanoside vs. control or $2 \mu \mathrm{m}$

glibenclamide

Non- Incubated isolated islet

diabetic rat cells with/without the substances
Incubated isolated islet

cells with/without the

substance

$32 \mathrm{~h}$

Dose-dependent increase in basal insulin secretion

$24 \mathrm{~h}$

Increaseed basal insulin secretion and GSIS at all doses and by all cell types

$24 \mathrm{~h}$

Dose-dependent increase in basal insulin insulin/islet/h

Dose-dependent increase in GSIS at 0. 1-5 $\mathrm{mg} / \mathrm{ml}$ of HR II and HR IV vs. control, increase in GSIS at $5 \mathrm{mg} / \mathrm{ml} \mathrm{HR}$ III vs. control secretion and GSIS at all doses over $50 \mu \mathrm{U}$

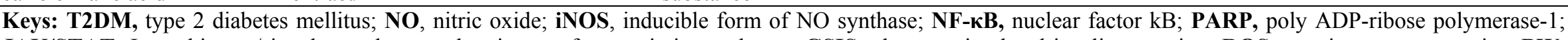

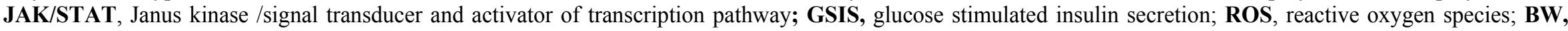

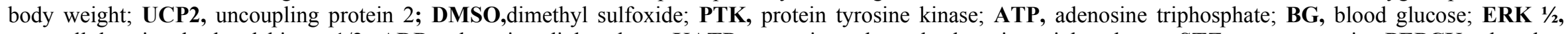

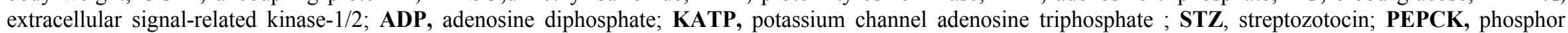

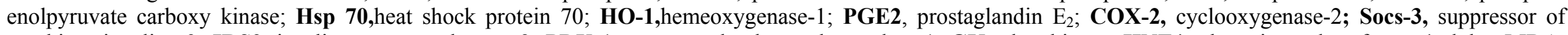

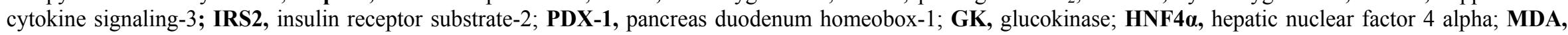

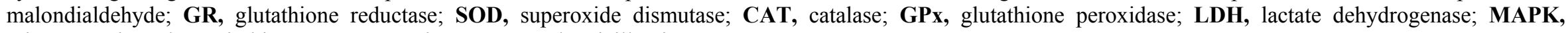
mitogen-activated protein kinase; SNAP, S-nitroso-N-acetylpenicillamine. 